\title{
Two Parables on "The Wealthy Father and the Poor Son" in the Saddharmapundarika and the Mahäbherisütra
}

\author{
Suzuki Takayasu
}

\section{The Aim of This Paper}

The Adhimukti-parivarta (Chapter on the Mental Disposition; SP 4) ${ }^{1)}$ in the Saddharmapundarika (Lotus Sutra, SP) ${ }^{2)}$ has a famous parable known as "The Wealthy Father and the Poor Son"3) teaching the ekayāna (one vehicle) theory that any sentient being including arhat can attain buddhahood. The abstract of this parable is as follows:

A wealthy man had a son, but the son went away from his father and lived as a poor wanderer for a long time. His father moved to another country looking for his son who had disappeared. Not knowing that the wealthy man was his real father, the poor man by chance came to the place where his father resided. Terrified by the wealthy man's dignity he soon ran away. Becoming aware that the poor man was his son, the wealthy man sent his men and made them bring him. Since the poor man was so terrified and fainted in fear, his father let him go and later sent some other men to him and made them invite him to take a job as a night soil cleaner in the wealthy man's house.

One day the wealthy man who wore dirty clothes and pretended to be poor approached his son and assured him that he could work here safely and promised to treat him like his real son. Twenty years passed and the wealthy man came to realize that the time of his death was coming near. He called the poor man and appointed him as an administrator of the property. Finally on his deathbed he gathered the king and his relatives, and revealed the truth that he and the poor man were really father and son. Thus the poor man inherited all the property of his father.

The same parable is also found in the Mahābherīsutra $(M B h S),{ }^{4)}$ which was chiefly compiled under the influence of the $S P$ and the Mahäparinirvānasütra (MPNS) and is one 
of the Mahāyāna sūtras teaching the tathāgatagarbha-buddhadhātu theory. These two parables share the same theme and core story, but at the same time there exists one great difference between them. In the parable in the $S P$ the poor man, who is in fact the only son of the wealthy man and works for him not knowing that the man is his real father, never wishes for the property. Having been told the truth that they are really father and son, he unexpectedly becomes an heir. This parable is told by the following four arhats: Subhüti, Mahākātyāyana, Mahākāśyapa, and Mahāmaudgalyāyana. ${ }^{5)}$ In the parable in the $M B h S$, on the contrary, the poor man is already eager to have the property before being told the truth, and becomes the heir as he wished after his father's declaring the truth. ${ }^{6)}$ This parable in the $M B h S$ is told not by arhat but by the Buddha Sākyamuni. This paper attempts to elucidate the reason which brought about the difference between the two parables on "The Wealthy Father and the Poor Son" referring to the ekayāna theory and the idea of moksa (liberation from the world of existence) in both scriptures.

\section{The Ekayāna Theory and the Idea of Mokșa in the SP}

The poor son in the parable in the $S P$ who never wishes to have the property depicts the Buddha's disciple, especially arhat who has already attained moksa. In India, where the idea of samsāra (metempsychosis; the transmigration of the soul / the endless cycle of death and rebirth) is generally believed, if those who attained moksa die, they will never come back to the world of existence, and they enter into their peacefulness. The arhats in the $S P$ lament because they have been liberated from the world of existence by not attaining buddhahood but arhathood. It is true that there exists a chance of their attaining buddhahood only if they accomplish their practice for the supreme enlightenment in this life. But they will not do so because they feel they have become very old and weakened and have little time or energy to practice in this life. If they die they will be entering into their peacefulness and no longer have a chance to practice for the supreme enlightenment. This is the reason why the arhats in the $S P$ will not wish to attain the supreme enlightenment nor practice for it even if they fully know its value. ${ }^{7)}$ Just as these arhats, the poor man in the parable in the $S P$ does not wish to attain the property of the wealthy man because the poor man does not know that they are really father and son. In India normally the heir of the property of a father will be his son. Therefore the poor man has never wished for the property of the wealthy man since he believes that it is impossible for him. Thus in accordance 
with the idea generally accepted in Indian society the $S P$ tries to explain why the arhats have never wished for the supreme enlightenment even if they fully know its value.

To them the Buddha Śākyamuni in the $S P$ reveals the ekayāna theory that all the sentient beings can attain buddhahood. ${ }^{8)}$ As to the reasons why everyone can attain buddhahood, the SP explains that in order to lead everyone to the supreme enlightenment all the Buddhas including the Buddha Śākyamuni appear in this world and that to enable everyone to attain buddhahood is the vow of all the Buddhas. ${ }^{9)}$ Here we can see that the SP finds the grounds of the everyone's attainment of buddhahood outside of sentient beings.

The SP proclaims that he who has practiced siunyata (the emptiness) and attained arhathood has not attained the supreme enlightenment yet. ${ }^{10)}$ Since the adhimukti (mental disposition) of śrāvakas (the Buddha's disciples) is still inferior before attaining arhathood, they cannot understand or accept the possibility of their attaining buddhahood. ${ }^{11)}$ Therefore the Buddha Śăkyamuni in the $S P$ shows them the tentative goal, that is, arhathood, and intentionally leads them there by such inferior teaching as the siunnyat $\bar{a}$ theory. ${ }^{12)}$ Attaining arhathood and mokșa, however, they at last realize the importance and the value of the supreme enlightenment. ${ }^{13)}$ But, as mentioned above, they still remain unwilling to attain it because as the aged arhats who have already attained mokșa they feel sure they have little time or energy to practice for the rest of this life. ${ }^{14)}$ Seeing that they already realized the importance and the value of the supreme enlightenment and lament being unable to attain it, the Buddha Śākyamuni confirms that their adhimukti has fully developed and tells them that even arhat who has already been liberated from the world of existence can attain nirvāna (perfect peacefulness) and mokșa as buddha. ${ }^{15)}$ We can here notice two points: First, in the $S P$ the development of the Buddha's disciples' adhimukti can be confirmed whether they realize the importance and the value of the supreme enlightenment and lament being unable to attain it or not. Second, the SP attempted to change the definition of moksa. In general understanding mokșa is the liberation from this world of existence, and one who has attained mokșa will never return to this world. The $S P$, however, in order to assure all the sentient beings including arhats who have already attained moksa of their possibility of attaining the supreme enlightenment challenged the general understanding of moksa, ${ }^{16)}$ and proposed a surprising idea that the liberation from this world of existence is not the real mokșa. 


\section{The Ekayāna Theory and the Idea of Mokșa in the MBhS}

Just as the $S P$, the $M B h S$ insists that the goal of any religious practice in Buddhism is attaining the supreme enlightenment, that is, to become buddha. ${ }^{17)}$ The vehicle to the buddhahood is always the same throughout (ekayāna), so there is no need for them "to transfer from one to the other." Only its name varies in accordance with the development of the sentient beings from śrāvaka, through pratyekabuddha and bodhisattva, and to tathägata. ${ }^{18)}$ According to this development, the sentient beings gradually and naturally realize by themselves that their goal is buddhahood, not arhathood. ${ }^{19)}$

As to the reason why everyone can attain buddhahood, the $M B h S$ explains that there exists buddhadhātu (the element, the essence, or the cause of the buddha) within all the sentient beings and by this buddhadhātu everyone can attain buddhahood. ${ }^{20)}$ Here we can see that the $M B h S$ finds the grounds of the everyone's attainment of buddhahood within sentient beings.

The $M B h S$ proclaims that he who has practiced only śünyata cannot attain the supreme enlightenment since the Buddha does not declare the real meaning yet in the traditional ś $\bar{u}$ nyat $\bar{a}$ theory. ${ }^{21)}$ One can attain mokșa over and over again until he attains the ultimate mokșa when becoming buddha. ${ }^{22)}$ Since it is already revealed in the $S P$ that the arhathood is not the ultimate goal, arhat in the $M B h S$ wishes by himself for the attainment of the supreme enlightenment. ${ }^{23)}$

\section{The Reason for the Difference between the Two Parables}

Through the above examination in Chapter 2 and Chapter 3, we seem to have acquired a clue to the solution of the problem as to the great difference between the two parables: while the poor man in the SP never wished for the property and became the heir after having been told that he is the one and only son of the wealthy man, the poor man in the $M B h S$ already wished to have the property before being told that he is the son. The clue can be found in the difference between these two sutras regarding why all the sentient beings have the possibility of attaining buddhahood.

Since the $S P$ assures all the sentient beings of their attaining buddhahood on the grounds that in order to lead them to the supreme enlightenment all the Buddhas appear in this world and to enable them attain buddhahood is the vow of all the Buddhas, in the $S P$ the 
grounds for the everyone's attainment of buddhahood lies outside of sentient beings, not within them. Therefore they cannot know their possibility of attaining buddhahood without the Buddhas' instruction. ${ }^{24)}$ These sentient beings denote the poor man in the parable in the $S P$ who never wished for the property before being told that he is the heir.

In the $M B h S$, on the contrary, the grounds of all the sentient beings' attaining buddhahood lies within themselves as buddhadhätu. They need not be told by the Buddhas of their possibility of attaining buddhahood. In accordance with their development of the practice they realize by themselves that they can attain buddhahood, and they naturally wish for it. These sentient beings denote the poor man in the parable in the $M B h S$ who wished for the property before being told that he is the heir.

It is true that the parable on "The Wealthy Father and the Poor Son" in the MBhS may seem unnatural in Indian society where the birth (caste, $j \bar{a} t i$ ) is very highly regarded. In the light of "the common sense in Indian society," the poor man's demand that he wants to become an heir of the wealthy man before being told the truth that they are really father and son seems thoughtless and against the common sense among the lay people in India. But Indian Buddhism which has been transmitted and practiced by the renouncers such as monks traditionally has had an idea of the supermundane relationship between father and son, that is, the Buddha and his disciple are in Indian Buddhist context really father and son. ${ }^{25)}$ While the parable in the $S P$ is still based on the mundane common sense of Indian society (because as the pioneer and introducer of this parable the $S P$ must have done so), the $M B h S$, which inherited this parable from the $S P$, became able to interpret this parable within the supermundane Buddhist context. In the light of "the common sense of Indian Buddhism," the parable in the $M B h S$ can be said to be "more suitable to a supermundane context," and we can say that the idea shown in the parable in the MBhS belongs to the mainstream of Indian Buddhism which has been based not on one's birth, but one's action.

\section{Another Reason for the Interpretation in the $M B h S$}

As mentioned above regarding the reason for the difference between the two parables, the present author proposed the idea that the $M B h S$, as one of the Mahāyāna sūtras which teach the tathägatagarbha-buddhadhätu theory, assumes the ground of all the sentient beings' attaining buddhahood within themselves, and therefore without the instruction by the Buddha they will gradually come to seek buddhahood. We also see that the $M B h S$ attempt- 
ed to interpret the parable first introduced from the $S P$ along the traditional context shared by the Indian Buddhist renouncers and to adjust it to the supermundane common sense of Indian Buddhism.

There seems another reason for this interpretation in the $M B h S$. Whether the tath $\bar{a}$ gatagarbha-buddhadhatu theory is taught or not, the Buddha in both the $S P$ and the MBhS knows from the very beginning that the Buddha and his disciples are really father and sons. From the Buddha's point of view the wealthy man and the poor man in the parable are from the very beginning really father and son whether the son is told the truth or not. The previous studies ${ }^{26)}$ have already pointed out that the tathāgatagarbha-buddhadhātu theory is based on the Buddha's point of view, not on that of the ordinary people. As one of the scriptures that teach this theory there is the possibility of interpreting the parable from the Buddha's point of view in the $M B h S$. While the parable in the $S P$ is told by the disciples of the Buddha, the parable in the $M B h S$ is told by the Buddha Sākyamuni himself. This difference of the teller of the parable between the two scriptures may account for the hypothesis proposed in this paper.

1) $S P_{S} 100.1-120.9, S P_{T} 45 \mathrm{a} 1-53 \mathrm{~b} 3, S P_{C 2} 16 \mathrm{~b} 7-19 \mathrm{a} 11$.

2) 〈Texts and Abbreviations〉

SP Saddharmapundarika.

$S P_{S} \quad$ Saddharmapundarīka, ed. H. Kern and Bunyiu Nanjio. St. Petersburg: Bibliotheca Buddhica, 1908-1912.

$S P_{M S} \quad$ Sanskrit Manuscripts of Saddharmapundarika. Tokyo: Publishing Association of Saddharmapundarika Manuscripts, 1977-1982.

$S P_{T} \quad$ Tibetan version of the SP, P No. 781 (Dam pa'i chos pad ma dkar po).

$S P_{C 2} \quad$ Second Chinese version of the $S P, T$. No. 262 (Miaofa lianhua jing 妙法蓮華經), trans. Kumārajīva.

MBhS Mahäbherīsūtra.

$M B h S_{T} \quad$ Tibetan version of the $M B h S$, P No. 888 ( $r \dot{N} a$ bo che chen po' $i$ mdo).

$M B h S_{C} \quad$ Chinese version of the $M B h S$, T. No. 270 (Da fagu jing 大法鼓經), trans. Gunabhadra. VKN Vimalakirtinirdeśa.

$V K N_{S} \quad V i m a l a k i r t i n i r d e s ́ a: A$ Sanskrit Edition Based upon the Manuscript Newly Found at the Potala Palace. Tokyo: Taisho University Press, 2006.

(T. Taisho Tripitaka; P Peking Kanjur)

3) $S P_{S} 101.11-108.15,111.1-115.12, S P_{T} 45 \mathrm{~b} 8-49 \mathrm{a} 6,50 \mathrm{a} 8-52 \mathrm{a} 3, S P_{C 2} 16 \mathrm{~b} 25-17 \mathrm{~b} 17,17 \mathrm{c} 13-$ $18 \mathrm{~b} 10$.

4) $M B h S_{T} 116 \mathrm{a} 6-117 \mathrm{a} 2, M B h S_{C} 297 \mathrm{~b} 22-\mathrm{c} 14$. 
5 ) In the prose part these four arhats tell this parable. But in the verse part it is only told by Mahākāśyapa.

6 ) Kariya [1983] pointed that the story of the parable in the $M B h S$ seems unnatural in Indian society. Kariya Sadahiko 荻谷定彦 [1983], Hokekyō Ichibutsujō no shisō 法華経一仏乗の思想（Osaka: Tōhō Shuppan).

7) $S P_{S} 60.3-61.1,100.8-101.5, S P_{T} 28 \mathrm{a} 5-\mathrm{b} 6,45 \mathrm{a} 5-\mathrm{b} 5, S P_{C 2} 10 \mathrm{c} 1-11,16 \mathrm{~b} 13-20$.

$8) S P_{S} 40.13-15,46.11-12,91.7-8,118.7-12, S P_{T} 19 \mathrm{~b} 5-6,23 \mathrm{a} 3-4,42 \mathrm{a} 3-4,52 \mathrm{~b} 7-53 \mathrm{a} 2, S P_{C 2} 7 \mathrm{~b} 2-$ $4,8 \mathrm{a} 17-18,15 \mathrm{a} 14-15,18 \mathrm{c} 15-19$, and so on.

9) $S P_{S} 40.3-9,53.3-4, S P_{T} 19 \mathrm{a} 4-\mathrm{b} 2,25 \mathrm{~b} 3, S P_{C 2} 7 \mathrm{a} 23-28,9 \mathrm{~b} 3-5$.

10) $S P_{S} 43.11-13,61.1-2,62.15-63.2,91.9-12,100.12-101.3, S P_{T} 21 \mathrm{~b} 8-22 \mathrm{a} 2,28 \mathrm{~b} 6-7,29 \mathrm{~b} 3-5$, 42a4-5, 45b1-3, $S P_{C 2} 7 \mathrm{~b} 29-\mathrm{c} 3,10 \mathrm{c} 11-13,11 \mathrm{a} 12-17,15 \mathrm{a} 16-20,16 \mathrm{~b} 16-19$.

11) $S P_{S} 104.8-105.2,109.10-110.7,113.9-10,116.1-2, S P_{T} 47 \mathrm{~b} 1-2,49 \mathrm{~b} 6-50 \mathrm{a} 4,51 \mathrm{a} 5-6,52 \mathrm{a} 3, S P_{\mathrm{C} 2}$ $16 \mathrm{c} 29-17 \mathrm{a} 4,17 \mathrm{~b} 29-\mathrm{c} 8,18 \mathrm{a} 14-15,18 \mathrm{~b} 11-12$.

12) $S P_{S} 46.13-14,106.13-107.8,108.16-17,109.1-10, S P_{T} 23 \mathrm{a} 4-5,48 \mathrm{a} 7-\mathrm{b} 4,49 \mathrm{a} 6-7,49 \mathrm{a} 8-\mathrm{b} 6$, $S P_{C 2} 8 \mathrm{a} 19-22,17 \mathrm{a} 21-29,17 \mathrm{~b} 18-19,17 \mathrm{~b} 20-28$.

13) $S P_{S} 60.3-6, S P_{T} 28 \mathrm{a} 5-8, S P_{C 2} 10 \mathrm{c} 1-4$.

14) $S P_{S} 100.8-101.3, S P_{T} 45 \mathrm{a} 5-\mathrm{b} 3, S P_{C 2} 16 \mathrm{~b} 13-19$.

15) $S P_{S} 91.9-12,92.7-12,137.5-9,140.7-10,142.3-4,186.3-8,186.12-187.1,189.5-11,197.9-$ 198.10, $S P_{T} 42 \mathrm{a} 4-5,42 \mathrm{a} 8-\mathrm{b} 3,60 \mathrm{~b} 5-8,61 \mathrm{~b} 7-8,62 \mathrm{a} 7,82 \mathrm{a} 4-8,82 \mathrm{~b} 2-3,83 \mathrm{~b} 2-7,86 \mathrm{a} 5-\mathrm{b} 2, S P_{C 2} 15 \mathrm{a} 16-$ 20, 15a28-b7, -, 一, 一, 25c13-19, 25c22-23, 26a18-21, 27a23-b8.

16) For example, we can see the general understanding of moksa in the $V K N_{S} 37 \mathrm{~b} 6$.

17) $M B h S_{T} 110 \mathrm{~b} 7-111 \mathrm{a} 1,117 \mathrm{a3}-4, M B h S_{C} 295 \mathrm{c} 28-296 \mathrm{a} 6,297 \mathrm{c} 18-21$.

18) $M B h S_{T} 110 \mathrm{~b} 7-111 \mathrm{a} 1,112 \mathrm{a} 7-\mathrm{b} 1, M B h S_{C} 295 \mathrm{c} 28-296 \mathrm{a} 6,296 \mathrm{~b} 3-5$. The former is influenced by the $M P N S$, and the latter is by the $S P$.

19) $M B h S_{T} 110 \mathrm{~b} 7-111 \mathrm{a} 1,116 \mathrm{~b} 4-117 \mathrm{a} 2, M B h S_{C} 295 \mathrm{c} 28-296 \mathrm{a} 6,297 \mathrm{c} 4-14$.

20) sems can thams cad dan/ srog chags thams cad la sans rgyas kyi khams yod de (" asti buddhadhātuh sarvasattvaprānișu)/ mtshan dañ dpe byad bzan po mtha' yas pas brgyan pa na snañ bar 'gyur źin'/ khams des ( ${ }^{*}$ tena dhātunā) sems can mams kyis mya nan las 'das pa 'thob par 'gyur ro// $\left(M B h S_{T}\right.$ $\left.115 \mathrm{a} 8-\mathrm{b} 1, M B h S_{C} 297 \mathrm{~b} 1-2\right)$

21) $M B h S_{T} 112 \mathrm{a} 7-113 \mathrm{a} 4, M B h S_{C} 296 \mathrm{~b} 3-21$. This idea on śūnyatā was already proposed in the $S P$, the Mahāmeghasūtra, the MPNS, and the Angulimālīyasūtra.

22) $M B h S_{T} 110 \mathrm{~b} 1-111 \mathrm{a} 1,112 \mathrm{a} 7-\mathrm{bl}, M B h S_{C}$ 295c20-296a6, 296b3-5. This idea on mokșa was already proposed in the $S P$.

23) $M B h S_{T} 116 \mathrm{~b} 4-117 \mathrm{a} 2, M B h S_{C} 297 \mathrm{c} 4-14$.

24) After the Buddha Śākyamuni's having entered into his perfect peacefulness (parinirvrta), the $S P$ itself or the preachers of the $S P$ themselves will be taking over the role of the Buddha Sākyamuni telling people their possibility of attaining buddhahood. We can see here the idea of dharmakayya, the idea of the eternalness of the Buddha Śākyamuni, and the idea of the identification of tathägata and the preacher of the SP. See Suzuki [2006]. Suzuki Takayasu 鈴木隆泰 [2006], “Tathāgato Veditavyah: 
(176) Two Parables on "The Wealthy Father and the Poor Son" in the Saddharmapundarika and the Mahābherisūtra (T. Suzukı)

Nyorai de aru to shirinasai" Tathāgato Veditavyaḥ: 如来であると知りなさい, in Hokekyō to Daijō kyōten no kenkyū 法華経と大乗経典の研究, ed. Mochizuki Kaishuku 望月海淑（Tokyo: Sankibō Busshorin).

25) The typical expression on this subject can be found in Chapter 3 of the SP (adyāham bhagavan bhagavatah putro jyeștha auraso mukhato jāto dharmajo dharmanirmito dharmadāyādo dharmanirvurttah/ $\left[S P_{S} 61.2-3, S P_{T} 28 \mathrm{~b} 7-8, S P_{C 2}\right.$ 10c13-14.]). Takasaki Jikidō 高崎直道 [1974], Nyoraizō shisō no keisei 如来蔵思想の形成 (Tokyo: Shunjūsha). Kubo Tsugunari 久保継成 [1983], "Hokekyō no shūkyō-teki jissen” 法華経の宗教的実践, in Hokke shisō 法華思想, ed. Hirakawa Akira 平川彰, Kajiyama Yūichi 梶山雄一, and Takasaki Jikidō, Kōza Daijō Bukkyō 講座·大乗仏教 4 (Tokyo: Shunjūsha).

26) Takasaki $[1974]$ is the representative.

〈Key words〉 Miaofa lianhua jing, 妙法蓮華經, Fahua jing, 法華經, Saddharmapundarika, Xinjie pin, 信解品, Adhimukti-parivarta, Da fagu jing, 大法鼓經, Zhangzhe qiongzi yu, 長者窮子喻, parable on "The Wealthy Father and the Poor Son," the reasons why all the sentient beings can attain buddhahood, the one vehicle theory, the tathägatagarbha-buddhadhātu theory

(Professor, Yamaguchi Prefectural University, D.Litt.) 